\title{
Greater Arab Free Trade Area and practical challenges
}

\author{
Dr. Atia Hussain \\ Friedrich-Alexander-Universität Erlangen-Nürnberg, Germany
}

\begin{abstract}
The Gulf Cooperation Council (GCC) member states including Kingdom of Saudi Arabia (KSA), United Arab Emirates (UAE), Kingdom of Oman, Bahrain, Kuwait and Qatar being part of various Free Trade Agreements (FTAs) benefit from the preferential rate of customs duty for trading the goods among member states of the FTAs. This paper describes the practical challenges of Greater Arab Free Trade Area (GAFTA). In theory, GAFTA provides customs duty benefits to the member states trading parties subject to the fulfillment of specific conditions e.g. local value addition rule, transportation of goods, preferential origin of goods and direct invoicing. However, in practice the multinational businesses with global footprints face practical challenges whilst availing the GAFTA preferential customs duty benefits e.g. in triangular transactions. The challenges arise from the interconnected rules and regulations, which form the criteria for availing the benefits of GAFTA. There are ongoing discussions among the relevant governmental authorities of GAFTA member states to resolve these issues. This paper aims to articulate the practical challenges and suggests possible solutions to mitigate these challenges, which can facilitate the businesses to avail the GAFTA customs duty benefits.
\end{abstract}

Keywords: Free Trade Agreements; triangular transaction; direct invoicing; certificate of origin; local value addition.

\section{Introduction}

The GCC member states are part of various FTAs inter alia GCC, GAFTA, GCC-Singapore FTA and GCC-European Free Trade Association (EFTA) FTA. The import of goods into the GCC countries from the member countries of these FTAs shall be free from customs duties subject to the rules of origin of the specific FTA.

The GAFTA agreement was implemented in 1998 by more than 20 Arab countries ${ }^{1}$ to facilitate and develop trade among Arab states. The main traded products among GAFTA member states comprise of fuel, manufactured products, food items, chemical and machinery (Abedini \& Péridy, 2008). The key objectives of GAFTA agreement are far reaching as it not

\footnotetext{
${ }^{1}$ Algeria, Bahrain, Djibouti, Egypt, Iraq, Jordan, Kuwait, Lebanon, Libya, Morocco, Mauritania, Oman, Palestine, Qatar, KSA, Sudan, Syria, Somalia, Tunisia, UAE and Yemen.
} 


\section{$g^{\text {th }}$ International Conference on Modern \\ Research in \\ Management, Economics and \\ Accounting}

May 03-05 2019, Athens - Greece

only includes tariff reduction, but also extended market access among member states, harmonized, uniform implementation of customs procedures, trade facilitation (Malkawi, 2017) and removal of monetary, administrative and quantitative quotas (Abedini \& Péridy, 2008). Under the GAFTA agreement, goods that obtain origin within any of the GAFTA member states should conditionally be eligible for preferential treatment upon importation into other GAFTA member country (Malkawi \& El-Shafie, 2019). Generally, this would mean that goods of "Arab" origin would be eligible for an exemption from customs duty upon importation into another GAFTA member country. However, the practical application of the agreement varies among member states.

The article consists of five sections including introduction in the first part. Second section briefly explains the GAFTA conditions, which are required by the businesses to fulfil for availing the preferential customs duty benefits. Third section highlights the practical challenges of GAFTA specifically for triangular business transactions. Fourth section proposes various suggestions to the trading companies as well to the GAFTA governmental authorities in order to cope with the challenges of GAFTA by concluding the work in fifth section.

\section{Conditions of GAFTA}

The traders can avail customs duty preferential benefits within the provisions of GAFTA subject to the fulfilment of following conditions:

\subsection{Local value addition}

The provisions of GAFTA rules of origin state that there must be at least $40 \%$ local value addition in the production of the imported goods in a GAFTA member state in order for the goods to be treated as Arab origin and to avail GAFTA customs duty preferential benefits. ${ }^{2}$

\subsection{Certificate of Origin (COO)}

According to the GAFTA provisions, the goods that are traded between GAFTA member states for availing the customs duty benefits should be accompanied with an Arab COO. ${ }^{3}$

Rule 16 of Arab rules of origin for implementing the GAFTA states that the COO should include the name and address of the manufacturer, the number and date of the shipping invoice signed by the exporter. It should also state the name of the importer in the GAFTA destination country, product details i.e. type, weight, value etc. In addition, the products should show a clear

\footnotetext{
${ }^{2}$ Rule 2 (2) of Arab rules of origin for the purpose of implementing the agreement to facilitate and develop trade among Arab states (GAFTA).

${ }^{3}$ Rule 16 of Arab rules of origin for the purpose of implementing the agreement to facilitate and develop trade among Arab states (GAFTA).
} 


\section{$g^{\text {th }}$ International Conference on Modern \\ Research in \\ Management, Economics and \\ Accounting}

May 03-05 2019, Athens - Greece

and non-removable mark of origin according to the nature of the goods. The validity period for $\mathrm{COO}$ is for a period of four months from the date of its issuance in the exporting country. ${ }^{4}$

\subsection{Direct shipment}

Rule 17 of Arab rules of origin for implementing the GAFTA regulates another condition to avail the GAFTA customs duty preferential benefits i.e. the goods shall be transported directly from one GAFTA member state to other without passing through a non-GAFTA country.

There are exceptions to this rule in case of trans-shipment or temporary warehousing in nonGAFTA country subject to the condition that the goods remain under customs control and the goods do not undergo any operations apart from unloading, reloading or any operation to preserve them in good condition. ${ }^{5}$

\subsection{Invoicing}

Article 17 of GAFTA states that in order to benefit from customs duty preferential benefits under the GAFTA agreement 'goods shall be traded among party-states directly and without mediation of a non-Arab party.' 6

\section{Challenges of GAFTA}

The above set of interlinked and binding conditions to avail GAFTA preferential customs duty benefits appear unpretentious. Nevertheless, in practice these conditions are entrenched, multifaceted and involve intricate set of requirements from trading companies established at global level. The key challenge of preferential FTA is making the rules of origin simple and transparent (Malkawi \& El-Shafie, 2019), (Jones \& Martin, 2012). However, the conditions of GAFTA become difficult to achieve specifically in case of triangular transactions. The triangular transactions constitute trading and movement of goods among three business entities (related or unrelated) operating in different countries including Arab and non-Arab countries.

\footnotetext{
${ }^{4}$ Rule 16 of Arab rules of origin for the purpose of implementing the agreement to facilitate and develop trade among Arab states (GAFTA).

${ }^{5}$ Rule 17 of Arab rules of origin for the purpose of implementing the agreement to facilitate and develop trade among Arab states (GAFTA).

${ }^{6}$ Article 17 Agreement to facilitate and develop trade among Arab states.
} 


\section{$g^{\text {th }}$ International Conference on Modern \\ Research in \\ Management, Economics and \\ Accounting}

May 03-05 2019, Athens - Greece

\subsection{Non-Arab COO}

The multinational companies face various challenges in order to leverage from the benefits of GAFTA preferential customs duty rates due to rules of origin requirements in triangular transactions involving at least one non-GAFTA country. For example, a company is established and operating from Germany, UAE and KSA. The goods are wholly manufactured in Germany and shipped to importers in the UAE along with the COO. The UAE entity distributes the goods to the customers located in the GAFTA region. In this scenario, the UAE and KSA entities would not be able to avail the GAFTA preferential benefits even though the goods are transported between the GAFTA member states i.e. UAE and KSA after the export from Germany. This is due to fact that the goods are wholly extracted/produced in Germany (nonGAFTA country) without $40 \%$ local value addition ${ }^{7}$ in any of the GAFTA member state. It is interesting to note that the local customs authorities also face difficulties in determining the $40 \%$ local value addition for granting the preferential treatment to goods (World Customs Organization, 2011).

The $40 \%$ local value addition in the production of goods in GAFTA member state becomes challenge for multinational companies having production plant, suppliers of raw material, machinery, equipment and human resource in non-GAFTA countries with widespread target market/customers in the GAFTA member states. Consequently, the nature of the rules of origin may challenge the abstract objectives of preferential trade agreements to encourage regional trade whilst jeopardizing the broader trade objective (Brenton et al., 2012). The impact of this challenge is equally applicable to the trade between two companies (one located in GAFTA and other in non-GAFTA country) where the local value addition in non-GAFTA country exceeds $60 \%$.

\subsection{Mediation of an Arab/non-Arab party invoicing}

According to Article 17 of GAFTA, 'goods shall be traded among party-states directly and without mediation of a non-Arab party.' There are discussions among governmental authorities of GAFTA member states to agree on the interpretation of this article. The term 'mediation' in invoicing flow is inferred contrarily by several GAFTA member states. Some GAFTA member states are of the view that there should be direct invoicing between two GAFTA member states without involvement of an Arab or non-Arab party in the transaction. However, the authorities of some of the GAFTA member states (e.g. KSA) has interpreted Article 17 that there could be mediation of an Arab party in the invoicing flow subject to the fulfilment of GAFTA rules of origin.

\footnotetext{
7 The $40 \%$ local value addition is calculated based on the net cost' method, or the final value of prodcuts. For additonal detais see Rule 3, Ch. 4, GAFTA.
} 


\section{$g^{\text {th }}$ International Conference on Modern \\ Research in \\ Management, Economics and \\ Accounting}

May 03-05 2019, Athens - Greece

In practice, most of the GAFTA customs authorities tend to grant no customs duty exemption benefits in case of mediation of an Arab or non-Arab party in the supply chain. They emphasize the condition of 'direct invoicing' and take the view that the same company should issue the $\mathrm{COO}$ and invoice used for customs declaration. This implies that in case of triangular transactions involving GAFTA member states (e.g. UAE $\rightarrow \quad$ Egyp $\rightarrow$ KSA) even if the 40\% local value addition rule in a GAFTA member state is satisfied (i.e. UAE entity). The ultimate importer of goods (i.e. KSA entity) would not be able to benefit from GAFTA customs duty exemption benefits, if the invoice is issued by a mediator GAFTA member state (i.e. Egypt entity).

The discrepancy in theoretical and practical interpretation of accepting an Arab mediator invoice was discussed among member states in GAFTA Implementation and Pursuit Committee meeting No. 44 at Cairo, Egypt. In this context, the proposal and approach presented by KSA was explicitly discussed ${ }^{8}$ which implied that the invoice issued by an Arab mediator (GAFTA member state) shall be accepted subject to the provisions of Article 17 of GAFTA i.e. 'goods shall be traded among party-states directly and without mediation of a non-Arab party.' Moreover, the general provisions of GAFTA rules and the Economic and Social council shall be observed. The Committee took a favourable position whilst analysing the suggested approach proposed by KSA and recommended that the mediation of an Arab party in invoicing shall be accepted for availing the GAFTA customs duty benefits subject to the fulfilment of rules of origin.

However, the Committee has recommended specific mechanism to interlink the Arab parties involved in a triangular transaction through COO. The name and country of the Arab party mediator shall be cited in the $\mathrm{COO}$ (box 7) issued by the exporter's country as: 'The final seller of these goods (name of the Arab mediator) in (the country of the Arab mediator).' The mediator's invoice shall refer to the number and date of the invoice of the exporter referred in the COO. ${ }^{9}$

The GAFAT member states are gradually implementing the Committee recommendation discussed in the meeting. Among others, the customs authorities of KSA has already implemented the specific mechanism advocated by the Committee through stating the name and country of Arab mediator in the box 7 of COO.

\footnotetext{
${ }^{8}$ General secretariat economic sector management of Arab economic integration. Implementation and pursuit committee meeting (44) Cairo: 26-28 December 2017, decisions and recommendations - second clause.

${ }^{9}$ General secretariat economic sector management of Arab economic integration. Implementation and pursuit committee meeting (44) Cairo: 26-28 December 2017, decisions and recommendations - second clause.
} 


\section{$g^{\text {th }}$ International Conference on Modern \\ Research in \\ Management, Economics and \\ Accounting}

May 03-05 2019, Athens - Greece

Notwithstanding, all GAFTA member states tend to agree on the interpretation of Article 17 that the invoicing flow and legal title flow should not constitute mediation of a non-Arab party. In a triangular transaction constituting (e.g. UAE $\rightarrow$ Germany $\rightarrow$ KSA), even if the goods are produced and have attained $40 \%$ local value addition in the UAE. Despite, the UAE entity can face issues in availing the GAFTA preferential customs duty benefits if the commercial invoice used for customs declaration purpose is issued by the German entity at the time of export of goods. This would lead to the mediation of a non-Arab party in the transaction and hence would violate the conditions of GAFTA.

\subsection{Non-Arab mediation in transportation of goods}

According to the provisions of GAFTA, the goods shall be transported directly from one GAFTA member state to other without passing through non-GAFTA countries. ${ }^{10}$ However, transportation of goods through another GAFTA country is allowed subject to the strict control of the customs authorities of the mediator country (Abreu, 2011). This implies that in case of triangular transactions involving only Arab states (e.g. UAE $\rightarrow$ Egypt $\rightarrow$ KSA), the goods can be passed through the intermittent GAFTA member state, if required.

However, in practice the customs authorities of the most GAFTA member states tend to decline the involvement of another GAFTA member states as mediator in the physical flow of goods for granting the GAFTA customs duty exemption benefits. The reason can be attributed to the difficulties in monitoring the movement and storage of goods under strict customs control in the intermittent GAFTA countries.

The triangular transactions involving non-GAFTA countries (e.g. UAE $\rightarrow$ KSA) even if the local value addition rules in GAFTA member states are observed, but the goods are transported directly from Germany, KSA entity would not be able to avail the GAFTA preferential customs duty benefits because the goods are not transported directly between the GAFTA member states. In addition, the goods will disqualify for their Arab origin status.

The practical limitation on the involvement of GAFTA and non-GAFTA countries as mediator in a triangular transaction for the physical flow of goods cause challenges for multinational companies operating in Arab and non-Arab countries.

\subsection{GAFTA trade involving Free Zones entities}

\footnotetext{
${ }^{10}$ Rule 17 of Arab rules of origin for the purpose of implementing the agreement to facilitate and develop trade among Arab states (GAFTA).
} 


\section{$g^{\text {th }}$ International Conference on Modern \\ Research in \\ Management, Economics and \\ Accounting}

May 03-05 2019, Athens - Greece

The Free Zones entities in the UAE are established to boost and facilitate the foreign investment. The foreign companies can invest in the Free Zones entities located in specific areas in the UAE (e.g. Jebel Ali Free Zone Area etc.) with $100 \%$ foreign ownership. In general, the Free Zones entities are seen as offshore locations and are treated as foreign territories for customs duty purpose. It implies that they are not considered within the scope of the GCC Customs Union. However, the GCC Customs Law applies in Free Zones with different practical and procedural implications in each Free Zone.

From GAFTA standpoint, the entities established in Free Zones are not deemed as part of GAFTA member states and treated as foreign entities (non-Arab party). Therefore, the involvement of Free Zones entities in a triangular transaction or direct supply chain (physical and/or invoice flow) will not adhere to the conditions of GAFTA for availing the customs duty exemption benefits. This ultimately limits the scope of the GAFTA benefits for trading companies operating in Free Zones areas in the UAE.

To boost up the foreign investment, UAE cabinet Ministers has decided a forthcoming change in the foreign ownership structure in the UAE mainland area. This change will allow the foreign companies to set up their entities on the UAE mainland area (non-Free Zone area) by owning $100 \%$ legal ownership. ${ }^{11}$ This may ultimately facilitate the foreign companies established on the UAE mainland area to benefit from GAFTA customs duty exemption. However, confirmation and securement of this duty exemption will be subject to GAFTA rules of origin.

\section{Suggestions}

The GAFTA is established to facilitate the trade among Arab member counties therefore, multinational trading companies shall invest in GAFTA countries by setting up their business operations, manufacturing units and production plants in the Arab countries. In this way, the $40 \%$ local value addition rule can be achieved by utilising the local (Arab origin) raw material in the production of goods.

In order to secure and retain the GAFTA customs duty benefits, the companies shall explore and develop more conducive supply chain solutions in line with the GAFTA rules of origin. This eventually will facilitate trade among Arab states by satisfying the conditions of GAFTA and by minimising the administrative cost of involving a non-Arab party in the invoicing or physical flow of goods. Moreover, this would help traders to manage their improbable

\footnotetext{
${ }^{11}$ Please note that for further interpretation and implementation of this approval, Ministry of Economy will issue a detailed report in near future.
} 


\section{$g^{\text {th }}$ International Conference on Modern \\ Research in \\ Management, Economics and \\ Accounting}

May 03-05 2019, Athens - Greece

expectations of leveraging the GAFTA benefits and bilateral trade cost by involving non-Arab mediator in supply chain of goods.

It is suggested to the government authorities of GAFTA member states that they shall simplify the rules of origin so that they should not become instrument of forced investment and burdensome for the businesses. The $40 \%$ local value addition rule can be reduced by facilitating traders on the basis of selected product specific industries.

The validity period of $\mathrm{COO}$ issued by the exporting country authorities is only four months. To facilitate trade among Arab countries, the validity period of $\mathrm{COO}$ can be extended for a period of twelve months or more. Similar to the short-term and long-term supplier's declaration certificate in Europe, the Arab countries authorities can introduce short-term and long-term COO for GAFTA. This will help traders to lower the administrative cost in obtaining the COO on a repetitive basis after each four months. It ultimately can support the traders for quick turnaround and swift delivery of goods to the importing country.

The customs authorities of GAFTA member states shall establish formal mechanism for the traders to obtain advance ruling on the possibility of availing the GAFTA customs duty benefits before they import goods in a GAFTA member state.

All the GAFTA member states shall uniformly comply with the rules of origin. This will simplify and expedite the import customs clearance process. Moreover, it will facilitate importing customs authorities in their assessment for granting the GAFTA customs duty exemptions benefits to the traders by avoiding any unexpected uncertainties of the traders at the arrival of shipment on the port.

\section{Conclusion}

The preferential customs duty benefits provided within the provisions of GAFTA are interconnected with multifaceted conditions which confines the scope for multinational businesses established in both GAFTA and non-GAFTA countries specially in triangular transactions. However, trading companies can leverage the benefits of GAFTA by establishing entities in the GAFTA member states. Moreover, they can trade within the regulated conditions of GAFTA without involving non-Arab party in invoice and goods flow. The governments of Arab countries have realised the practical issues and the governmental authorities of GAFTA member states are in discussion to resolve the challenges arising from GAFTA so that more businesses can take the benefits of GAFTA and ultimate objective of GAFTA i.e. 'trade facilitation' can be maximized. The specific mechanism discussed during the Committee meeting by interlinking Arab party mediator in the $\mathrm{COO}$ is a positive step taken by the GAFTA government authorities to facilitate triangular transactions. 


\section{$g^{\text {th }}$ International Conference on Modern Research in \\ Management, Economics and Accounting}

May 03-05 2019, Athens - Greece

\section{References}

Abedini, J. and Péridy, N. (2008). "The Greater Arab Free Trade Area (GAFTA): An Estimation of the Trade Effects," Journal of Economic Integration, pp. 1-22.

Abreu, D.M. (2013). "Preferential Rules of Origin in Regional Trade Agreements," WTO Staff Working Paper No. ERSD-2013-05, 13.

Agreement to facilitate and develop trade among Arab states, league of Arab states general secretariat. General department for economic affairs.

Arab rules of origin for implementing the agreement to facilitate and develop trade among Arab states (GAFTA).

Brenton, P., Kalenga, P. and Flatters, F. (2005). "Rules of Origin and SADC: The Case for Change in the Mid Term Review of the Trade Protocol," Africa Region Working Paper Series 2005, 83.

General secretariat economic sector management of Arab economic integration. Implementation and pursuit, Committee meeting (44) Cairo: 26-28 December 2017, decisions and recommendations.

Jones, V. C. and Martin, M. F. (2012). "International trade: Rules of origin," Congressional Research Service CRS Report for Congress, 7.

Malkawi, H. B. and El-Shafie, I. M. (2019). "The Design and Operation of Rules of Origin in Greater Arab Free Trade Area: Challenges of Implementation and Reform," Journal of World Trade, vol. 53 no. 2 pp. 243-272.

Malkawi, H. B. (2017). Reforming Rules of Origin in Greater Arab Free Trade Area for Effective Economic Integration. Economic Research Forum Brief. [Online]. 29. pp. 1-7. Available: https://issuu.com/sharjah48/docs/reforming_rules_of_origin_in_gafta

Malkawi, H. B. (2011). "Rules of Origin Under US Trade Agreements with Arab Countries: Are They Helping and Hindering Free Trade?" Journal of International Trade Law \& Policy, vol. 10 pp. 29-34.

World Customs Organization. (2011). "World Trends in Preferential Origin Certification and Verification,” WCO Research Paper No. 20, 18. 